\title{
Simulasi Pengaruh Kemiringan Atap Rumah Terhadap Hujan Pasir Erupsi Gunung Api
}

\author{
Tatas, Amien Widodo, Machsus, Muhammad Hafiizh Imaaduddiin \\ Pusat Studi Kebumian, Bencana dan Perubahan Iklim (PSKBPI), ITS \\ Email: the_tatas@yahoo.com
}

\begin{abstract}
Volcanic eruption of Mount Bromo in 2011 caused damage and loss to the community in four surrounding districts, which are Probolinggo, Pasuruan, Malang, and Lumajang. Rain of sand caused the area around mountain top covered with sand up to five kilometers. Sand covered the roofs of residentials as well as public facilities and infrastructures, such as schools and roads. The eruption that occurred in the rainy season caused sand that covered the roofs became more tacky and heavier which caused a heavy load on roofs of residential. Because the roof of the building was not designed for larger loads, it caused the roof structures failed to withstand the load of sand, and consequently a lot of roof structures collapsed. This study was conducted to provide a solution for houses in and around the volcano area, so that in case of rain of sand, the sand can easily slip down and does not accumulate on the roof of the houses. The method of study was to perform simulations of sand rain on different types of roofing, tile soil and concrete, zinc and asbestos. The sand used in this study was taken from the eruption of Mount Bromo in 2011 with dry and wet conditions. The final result obtained was the variation slope of the roof, in which the sand was not accumulated on the roof.
\end{abstract}

Keywords: volcanic sand, slope of the roof, Mount Bromo.

Abstrak

Letusan vulkanologi Gunung Bromo pada Tahun 2011 memberikan dampak kerusakan dan kerugian bagi masyarakat di empat kabupaten sekitarnya, yaitu Kabupaten Probolinggo, Kabupaten Pasuruan, Kabupaten Malang, dan Kabupaten Lumajang. Hujan pasir yang terjadi menyebabkan daerah di sekitar puncak tertutup pasir hingga radius lebih dari lima kilometer. Pasir tersebut menutup atap-atap permukiman serta sarana dan prasarana umum lainnya, seperti sekolah dan jalan. Letusan yang terjadi di musim hujan menyebabkan pasir yang menutup atap rumah menjadi lebih lekat dan berat. Hal tersebut menyebabkan beban berat pada atap permukiman. Karena atap bangunan tidak didesain untuk beban yang lebih besar, maka hal tersebut menyebabkan struktur atap tidak mampu menahan beban pasir sehingga atap permukiman banyak yang runtuh. Penelitian ini dilakukan untuk memberikan solusi bagi rumah-rumah yang berada di sekitar gunung berapi agar apabila terjadi hujan pasir, pasir dapat dengan mudah tergelincir turun sehingga tidak terkumpul di atap rumah. Metode yang digunakan adalah dengan melakukan simulasi hujan pasir pada berbagai jenis atap, genteng tanah dan beton, seng dan asbes. Pasir yang digunakan adalah pasir yang diambil dari hasil letusan Gunung Bromo di Tahun 2011 dengan kondisi pasir kering dan basah. Hasil akhir penelitian yang diperoleh adalah variasi kemiringan atap sehingga hujan pasir yang mungkin terjadi tidak terkumpul di atas atap.

Kata kunci: pasir vulkanik, kemiringan atap rumah, Gunung Bromo.

1. Pendahuluan

Gunung Bromo pada tanggal 4 Januari 2011 meletus dengan ditandai adanya lontaran lava pijar dan suara gemuruh. Letusan tersebut juga disertai hujan abu dan pasir, dampak erupsi Gunung Bromo tersebut melanda empat kabupaten yang langsung berbatasan dengan komplek Pegunungan Tengger. Empat kabupaten tersebut adalah Kabupaten Probolinggo Pasuruan, Malang, serta Lumajang (lihat Gambar 1) (BNPB, 2011). Berdasarkan kajian kerusakan dan kerugian akibat erupsi Gunung 
Bromo (BPBD Provinsi Jawa Timur, 2011), diperkirakan dampak bencana ini adalah senilai lebih dari 156 milyar rupiah. Kerusakan dan kerugian terbesar terjadi dari wilayah Kabupaten Probolinggo. Hal tersebut terjadi karena saat erupsi, arah angin dominan Timur Laut menuju Kabupaten Probolinggo, sehingga yang paling terdampak adalah Kabupaten Probolinggo.

Letusan yang disertai dengan hujan pasir yang cukup tinggi mengakibatkan atap rumah, gedung sekolah, tempat peribadatan, dan bangunan-bangunan lainnya di sekitar Gunung Bromo tertutup abu dan pasir. Selain itu, lahanlahan pertanian juga tertutup pasir sehingga gagal panen (lihat Gambar 2) (BPBD Provinsi Jawa Timur, 2011). Hujan pasir yang jatuh di atap bangunan tersebut tidak dapat jatuh (merosot) ke bawah, melainkan tertumpuk terus dan menebal. Erupsi yang terjadi di musim hujan tersebut juga menyebabkan pasir semakin erat daya ikatnya satu sama lainnya. Dengan bertambahnya daya ikat pasir, maka perilaku pasir akan semakin kompak, sehingga pasir akan semakin sulit tergelincir ke bawah. Hal tersebut menyebabkan pasir hasil erupsi tetap bertahan di atas atap bangunan. Akibat kandungan air di pasir, maka dapat menyebabkan pasir semakin bertambah berat, atau dengan kata lain berat jenis pasir meningkat. Hal tersebut menyebabkan beban yang dipikul oleh rangka atap juga semakin besar, dan ditambah dengan usia bangunan yang cukup lama sehingga berakibat pada runtuhnya atap bangunan.

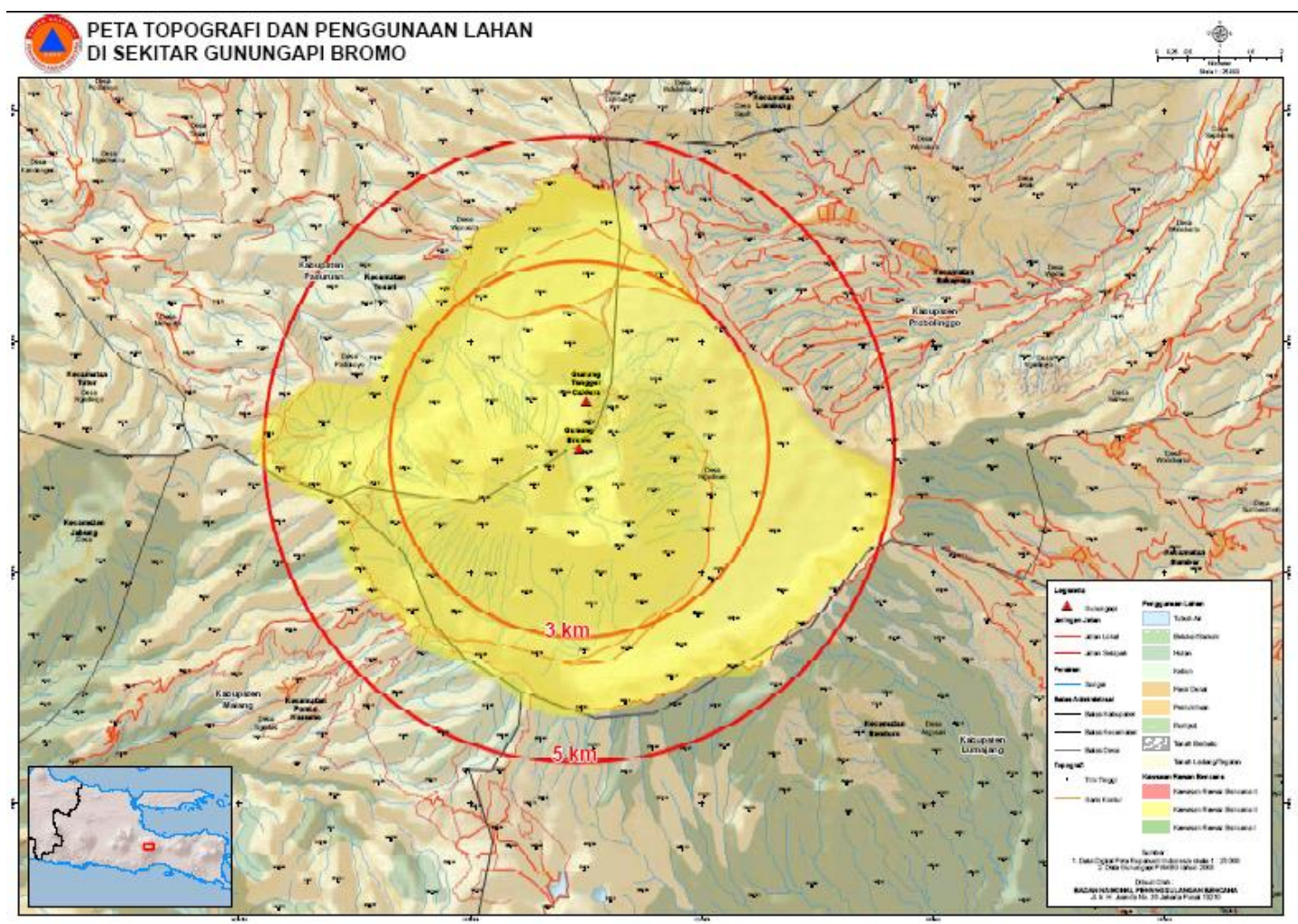

Gambar 1. Radius pengaruh erupsi Gunung Bromo, pada jarak $3 \mathrm{~km}$ dan $5 \mathrm{~km}$ dari pusat erupsi (BNPB, 2011). 


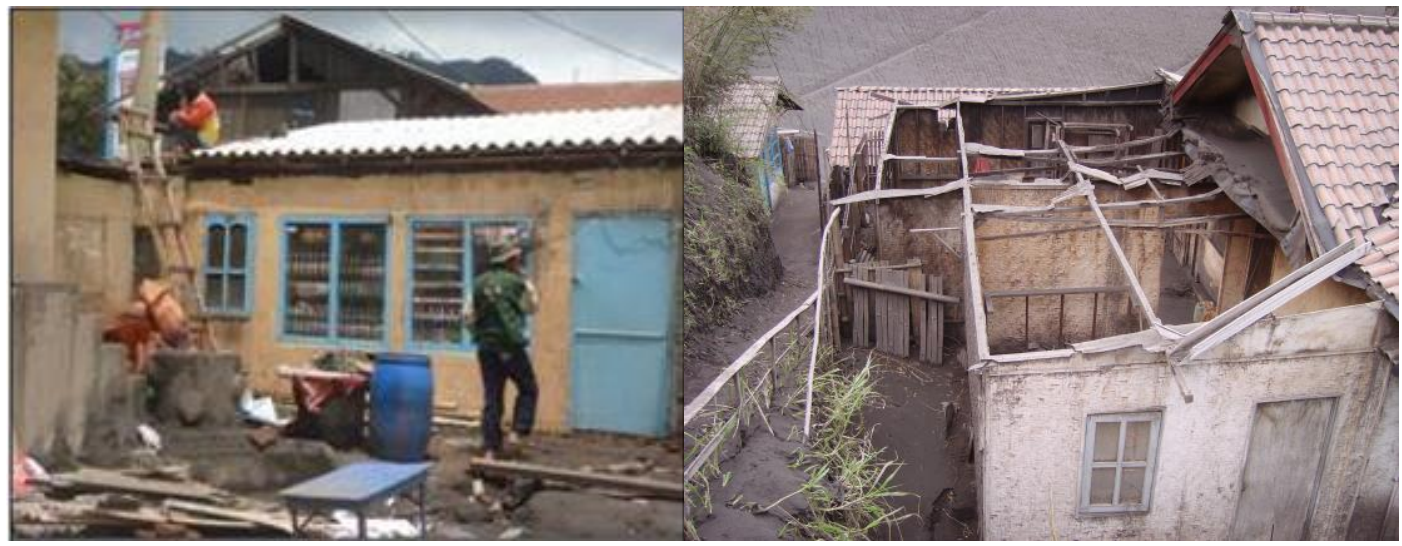

Gambar 2. Akibat hujan pasir di kawasan Gunung Bromo

Mekanisme air menjadi daya ikat antar partikel pasir (Das, 2010) adalah bahwa rongga kecil antar pasir yang terisi air dengan prosentase tertentu akan mengakibatkan adanya tegangan kapiler. Tegangan kapiler tersebut merupakan konsekuensi sifat adanya tegangan permukaan air. Tegangan kapiler yang terjadi tersebut bernilai negatif (menghisap), dan merupakan kebalikan dari tekanan hidrostatika yang bernilai positif (menekan). Semakin besar tegangan kapiler maka semakin besar tegangan efektif antar butiran tanah (Tegangan Total $=$ Tegangan efektif + Tegangan air) dan butiran pasir seperti saling terikat. Namun demikian, apabila airnya sangat banyak, maka pasir akan terpencar kembali karena tegangan hidrostatik menghilangkan tegangan kapiler.

Berdasarkan kondisi masalah di permukiman Gunung Bromo tersebut, penelitian ini ditujukan untuk mengetahui berapa kemiringan atap yang dapat direkomendasikan untuk bangunan di sekitar gunung berapi yang bila terjadi erupsi dan hujan pasir, pasir tidak menumpuk di atap tetapi dapat terge- lincir jatuh ke bawah. Sehingga tidak menambah beban rangka atap penopangnya, karena dalam perencanaan atap bangunan biasanya tidak pernah dikenakan beban akibat tumpukan pasir.

\section{Metodologi}

Metode yang digunakan adalah dengan membuat simulasi atap rumah sederhana yang dapat disesuaikan tingkat kemiringan atapnya (lihat Gambar 3). Jenis penutup atap yang digunakan untuk melakukan simulasi bervariasi yaitu: atap genteng tanah, atap genteng beton, atap asbes dan atap seng. Material pasir yang digunakan juga bervariasi dari tiga tempat hasil erupsi Gunung Bromo tahun 2011, yaitu dari Desa Ngadisari (dekat Kawah Bromo), Desa Ngadirejo, dan Desa Sambi Kerep. Kondisi pasir yang digunakan juga dibuat bervariasi, yaitu pasir dalam kondisi kering dan dalam kondisi basah.

\section{Hasil dan Pembahasan}

Berdasarkan hasil simulasi maka diperoleh data seperti yang terlihat pada Tabel 1. 


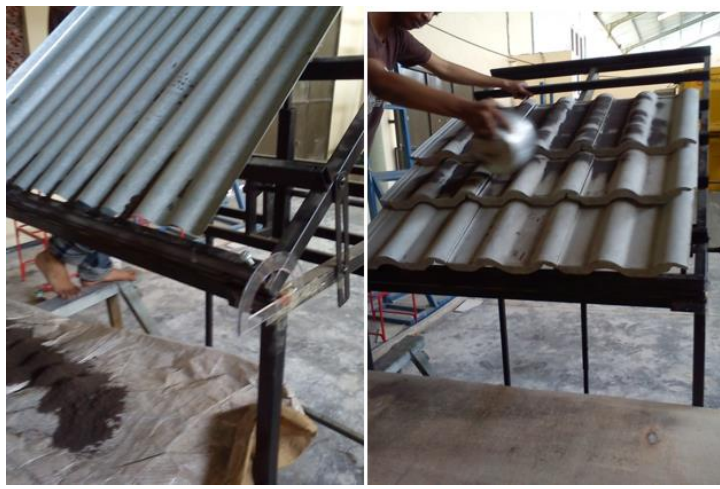

Gambar 3. Alat simulasi kemiringan atap.

Tabel 1 menunjukkan bahwa kemiringan atap untuk bangunan di kawasan gunung api yang membuat pasir terge- lincir jatuh atau tidak menumpuk di atap dipengaruhi oleh jenis penutup atap, lokasi bangunan dan kondisi pasir. Penutup atap yang digunakan pada penelitian ini meliputi: genteng tanah, genteng beton, asbes, dan seng. Lokasi bangunan yang dimaksudkan di sini terkait lokasi pengambilan sampel pasir, yang pada penelitian ini diambil dari Desa Ngadisari dan Sambikerep. Kondisi pasir disimulasikan dalam kondisi basah dan kondisi kering, untuk mewakili saat kondisi terjadi hujan maupun tidak terkena hujan.

Tabel 1. Hasil Simulasi Kemiringan Atap dengan Berbagai Bahan Penutup Atap dengan Pasir Hasil Erupsi Gunung Api

\begin{tabular}{|c|c|c|c|c|c|}
\hline & & \multicolumn{4}{|c|}{ Kemiringan Atap } \\
\hline \multicolumn{2}{|c|}{ Lokasi pengambilan sampel pasir } & \multicolumn{2}{|c|}{ Desa Ngadisari } & \multicolumn{2}{|c|}{ Desa Sambikerep } \\
\hline \multirow[b]{2}{*}{ Jenis Penutup Atap } & \multirow[b]{2}{*}{ Pergerakan Pasir } & \multicolumn{4}{|c|}{ Kondisi Pasir } \\
\hline & & Kering & Basah & Kering & Basah \\
\hline \multirow[t]{2}{*}{ Genteng Tanah } & Mulai Jatuh & $44^{\circ}$ & $45^{\circ}$ & $42^{\circ}$ & $46^{\circ}$ \\
\hline & Habis & $49^{\circ}$ & $49^{\circ}$ & $50^{\circ}$ & $49^{\circ}$ \\
\hline \multirow[t]{2}{*}{ Genteng Beton } & Mulai Jatuh & $37^{\circ}$ & $39^{\circ}$ & $38^{\circ}$ & $39^{\circ}$ \\
\hline & Habis & $41^{\circ}$ & $43^{\circ}$ & $44^{\circ}$ & $44^{\circ}$ \\
\hline \multirow[t]{2}{*}{ Asbes } & Mulai Jatuh & $35^{\circ}$ & $38^{\circ}$ & $35^{\circ}$ & $37^{\circ}$ \\
\hline & Habis & $38^{\circ}$ & $42^{\circ}$ & $40^{\circ}$ & $42^{\circ}$ \\
\hline \multirow[t]{2}{*}{ Seng } & Mulai Jatuh & $31^{\circ}$ & $37^{\circ}$ & $31^{\circ}$ & $39^{\circ}$ \\
\hline & Habis & $33^{\circ}$ & $40^{\circ}$ & $35^{\circ}$ & $40^{\circ}$ \\
\hline
\end{tabular}

Selanjutnya kemiringan atap untuk bangunan yang diperoleh pada simulasi ini dibandingkan dengan kemiringan atap eksisting yang umumnya yang terdapat pada lokasi studi. Berdasarkan hasil survey atau pengamatan lapangan diperoleh umumnya kemiringan atap genteng $30^{\circ}-35^{\circ}$, dan untuk atap seng atau asbes $10^{\circ}-15^{\circ}$. Perbandingan kemirigan atap hasil simulasi dengan kemiringan atap eksisting dapat menunjukkan tingkat risiko bencana dari kemiringan atap yang umumnya terdapat pada kawasan gunung api. Dengan demikian, hasil simulasi ini sangat penting dalam rangka Pengurangan Risiko Bencana (PRB) ambruknya atap bangunan akibat hujan pasir di kawasan gunung api

Pergerakan pasir bisa terjadi dan mulai jatuh pada sudut kemiringan atap terkecil, sebesar $31^{\circ}$ dengan jenis penutup atap seng dan pasir dalam kondisi kering. Pergerakan pasir dalam kondisi kering di atas penutup atap seng ini bisa sampai habis, jika sudut ke- 
miringan atapnya dinaikkan $2^{\circ}$ lagi atau menjadi $33^{\circ}$. Sementara pergerakan pasir bisa terjadi dan mulai jatuh membutuhkan sudut kemiringan atap terbesar, sebesar $46^{\circ}$ pada jenis penutup atap genteng tanah dan pasir dalam kondisi basah. Pada sudut kemiringan $49^{\circ}$ pergerakan pasir bisa sampai habis.

Berikut ini penjelasan lebih detail mengenai pengaruh dari variasi jenis penutup atap, lokasi bangunan, dari kondisi pasir terhadap sudut kemiringan atap di kawasan gunung api yang mampu membuat pasir tergelincir jatuh hingga habis.

a. Pengaruh Jenis Penutup Atap

Hasil simulasi pada Tabel 1 menunjukkan bahwa jenis penutup atap genteng tanah, genteng beton, asbes, dan seng memiliki pengaruh yang berbeda terhadap pergerakan pasir pada sudut kemiringan atap. Untuk jenis penutup atap genteng tanah pergerakan pasir terjadi pada sudut kemiringan atap sebesar $44^{\circ}$ (mulai jatuh) dan $49^{\circ}$ (habis) pasir dalam kondisi kering, dan sebesar $45^{\circ}$ (mulai jatuh) dan $49^{\circ}$ (habis) pasir dalam kondisi basah. Untuk jenis penutup atap genteng beton membutuhkan sudut kemiringan atap yang lebih rendah, begitu pula dengan penutup atap asbes dan seng, seperti tampak pada Tabel 1.

b. Pengaruh Lokasi Bangunan

Hasil simulasi pada Tabel 1 menunjukkan pergerakan pasir pada sudut kemiringan atap jika ditinjau dari lokasi bangunan tempat diambil sampel tanah, yaitu di Desa Ngadisari dan Sambikerep memang ada perbedaan, namun secara umum relatif sama. Hal ini berarti bahwa perbedaan lokasi pengambilan sampel tidak memiliki pengaruh signifikan terhadap sudut kemiringan atap. Ini sekaligus berarti bahwa sampel pasir atau abu vulkanik relatif homogen.

c. Pengaruh Kondisi Pasir

Hasil simulasi pada Tabel 1 menunjukkan bahwa kondisi kering dan basah memiliki pengaruh yang berbeda terhadap pergerakan pasir pada sudut kemiringan atap. Secara umum, sudut kemiringan atap pada kondisi kering lebih rendah dibandingkan dengan kondisi basah. Ini terjadi hampir pada semua jenis penutup atap, yaitu genteng tanah, genteng beton, asbes, dan seng. Ini menunjukkan bahwa pada kondisi basah lebih beresiko terhadap runtuhnya atap akibat tidak kuat menahan tambahan beban pasir diatasnya.

\section{Simpulan}

Berdasarkan analisis tersebut di atas dapat disimpulkan bahwa untuk bahan atap genteng tanah dan beton, yang kemiringan umumnya adalah $30^{\circ}-35^{\circ}$ direkomendasikan untuk ditambah kemiringan atapnya berturut-turut menjadi sampai dengan $44^{\circ}$ dan $49^{\circ}$. Sedangkan jika menggunakan atap asbes atau seng yang kemiringan umumnya adalah $10^{\circ}$ $15^{\circ}$ direkomendasikan untuk memasang atap bangunan dengan kemiringan $42^{\circ}$. Perbedaan lokasi pengambilan sampel pasir, yaitu sekitar 500 meter dari kawah dengan dari desa yang paling jauh terdampak tidak memberikan pengaruh yang signifikan, artinya dapat dikatakan bahwa rekomendasi kemiringan atap tersebut sebaiknya digunakan 
di lokasi yang memiliki potensi dampak terkena hujan pasir hasil erupsi. Kondisi pasir yang berbeda, kering dan basah, memperlihatkan bahwa perilaku keduanya berbeda yaitu kondisi basah memperlihatkan lebih sulit untuk tergelincir, sehingga dapat dikatakan bahwa pada musim hujan pasir akan lebih berbahaya jika menimpa atap rumah.

\section{Daftar Pustaka}

BNPB. (2011). Peta Penggunaan Topografi dan Penggunaan Lahan di Sekitar Gunung Api Bromo: Radius Pengaruh Erupsi Gunung Bromo. Jakarta.

BPBD Provinsi Jawa Timur. (2011). Rencana Program Rehabilitasi dan Rekonstruksi Pasca Erupsi Gunung Bromo. Laporan Akhir. Surabaya

Das, B. M., (2010). Principle of Geotechnical Engineering, 7th Edition. USA. 